症例

術後 1 年 2 カ月目に発生した直腸癌孤立性副腎転移の 1 例

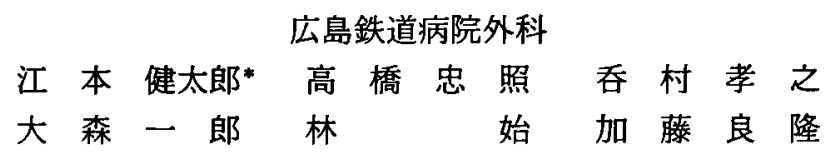

直腸癌の副腎転移はしばしば認められるが，外科的切除が可能であった孤立性副腎転 移は非常に稀である. 今回われわれは自験例を中心に本邦報告例 7 例について文献的考 察を加えて報告する。

症例は63歳の女性. 平成 8 年 2 月直腸癌胵浸潤の診断にて腹会陰式直腸切断術および 腟子宮合併切除術を施行した. 病理組織学上, 中分化型腺癌であり Stage IIIa であった. その後外来通院中に, CEA が徐々に上昇, 平成 9 年 4 月 CT 上, 左副腎腫湯を認めた. 内分泌検査では異常を認めず, 転移性副腎腫場の疑いにて同年 5 月, 摘出術を施行した. 組織学的検査の結果, 直腸癌の副堅転移と診断した。術後 7 カ月後の現在, 再発は認め られていない.

本邦報告例においていずれも腫瘍摘出後, 長期の生存が得られていることから, 発見 次第積極的に手術することが望ましいと思われた。

来引用語：直腸癌, 副腎転移

緒言

全覀性腫瘍の剖検例において副腎への転移は $14.8 \%$, また直腸癌からの転移は $2.2 \%$ と時折, 認めら れるが, 外科的切除が可能であった孤立性副腎転移は 非常に稀である1).

今回著者らは, 直腸癌の術後 1 年 2 力月目に左副腎 に孤立性転移を認めたため摘出術を施行した症例を経 験したので，本邦報告例 7 例とともに文献的考察を加 えて報告する。

\section{症例}

患者：63歳，女性.

主訴：腹部 CT 上の異常陰影.

家族歴：特記すへき事なし.

既往歴：特記すべき事なし。

現病歴：平成 8 年 2 月 28 日，当科で直腸㿋および腟 浸潤により腹会陰式直腸切断術, 子宮胵合併切除術を 施行した. 病理組織検查では中分化型腺癌であり媣達 度 ai, n1 (+), ow (-), aw (-) の Stage IIIa て あった. 術後5-FU の補助化学療法を行った後, 退院し

1997年11月25日受付 1998年 5 月19日採用

*現 : 三原市医師会病院外科
た. 以後,外来にて経過観察中であったが, 徐々にCEA が上昇したため,再発を疑い,CT を施行したものの明 らかな所見は認めなかった. 平成 9 年 4 月 1 日には CEA $55.5 \mathrm{ng} / \mathrm{ml}$ にまで上昇したため, 再度 CT を施行 したところ左副腎に腫瘍を認めたため, 精查加療目的 で平成 9 年 4 月 22 日, 当科入院となった。

入院時現症：負血，黄疸は認めなかった．腹部は平 坦, 軟で, 人工肛門と手術創を認める他は腫㿔等を触 知しなかった.

入院時検査成績：CEA が55. $5 \mathrm{ng} / \mathrm{ml}$ と高值である 以外は, 血液, 生化学検查に異常所見を認めなかった。

また，内分泌検査（血中コルチゾル，尿中VMA， 17-OHCS, 17-KS) でも異常を認めなかった（表 1).

腹部 CT 検査 : 肝, 腹腔内リンパ節に転移は認めな かったが, 左堅上極の前方に隣接して径約 $5.5 \mathrm{~cm}$ 大の 内部不均一な低濃度腫瘤を認めた（図 1).

血管造影検査：左中副腎動脈造影を施行したとこ ろ, 同動脈は腫大した左副腎により伸展され, 周囲に 不規則微細な tumor stain を認めた. hypovascularで あり，転移性腫場が強く疑われた（図 2 ).

以上より，直腸癌の孤立性左副腎転移と診断し，平 成 9 年 5 月 9 日手術を施行した。 
表 1 入院時検查所見

\begin{tabular}{lc|lc}
\multicolumn{3}{l}{ 血液, 生化学検査 } \\
\hline WBC & $3,400 / \mathrm{mm}^{3}$ & LDH & $426 \mathrm{IU} / l$ \\
$\mathrm{RBC}$ & $379 \times 10^{4} / \mathrm{mm}^{3}$ & $\gamma$-GTP & $9 \mathrm{IU} / l$ \\
$\mathrm{Hb}$ & $12.4 \mathrm{~g} / \mathrm{dl}$ & $\mathrm{BUN}$ & $10.8 \mathrm{mg} / \mathrm{dl}$ \\
$\mathrm{Hct}$ & $36.9 \%$ & $\mathrm{Cr}$ & $0.52 \mathrm{mg} / \mathrm{dl}$ \\
$\mathrm{Plt}$ & $13.2 \times 10^{4} / \mathrm{mm}^{3}$ & $\mathrm{Na}$ & $142 \mathrm{mEq} / l$ \\
T.Bil & $1.2 \mathrm{mg} / \mathrm{dl}$ & $\mathrm{K}$ & $3.9 \mathrm{mEq} / l$ \\
T.P & $6.2 \mathrm{~g} / \mathrm{dl}$ & $\mathrm{Cl}$ & $109 \mathrm{mEq} / l$ \\
Alb & $4.1 \mathrm{~g} / \mathrm{dl}$ & FBS & $95 \mathrm{mg} / \mathrm{dl}$ \\
T.cho & $248 \mathrm{IU} / l$ & CEA & $55.5 \mathrm{ng} / \mathrm{ml}$ \\
GOT & $21 \mathrm{IU} / l$ & CA19.9 & $5>\mathrm{U} / \mathrm{ml}$ \\
GPT & $6 \mathrm{IU} / l$ & & \\
\hline
\end{tabular}

\begin{tabular}{ccl}
\hline 副監機能検查 & & \\
\hline 血中アドレナリン & $0.036 \mathrm{ng} / \mathrm{ml}$ & $(0.12>)$ \\
ノルアドレナリン & $0.236 \mathrm{ng} / \mathrm{ml}$ & $(0.05 \sim 0.40)$ \\
ドーパミン & $0.024 \mathrm{ng} / \mathrm{ml}$ & $(0.20>)$ \\
コルチソール & $11.7 \mu \mathrm{g} / \mathrm{dl}$ & $(2.7 \sim 15.5)$ \\
尿中 VMA & $2.1 \mathrm{mg} / \mathrm{day}$ & $(1.9 \sim 5.9)$ \\
$17 . \mathrm{OHCS}$ & $2.8 \mathrm{mg} / \mathrm{day}$ \\
$17 . \mathrm{KS}$ & $2.9 \mathrm{mg} / \mathrm{day}$ \\
\hline
\end{tabular}

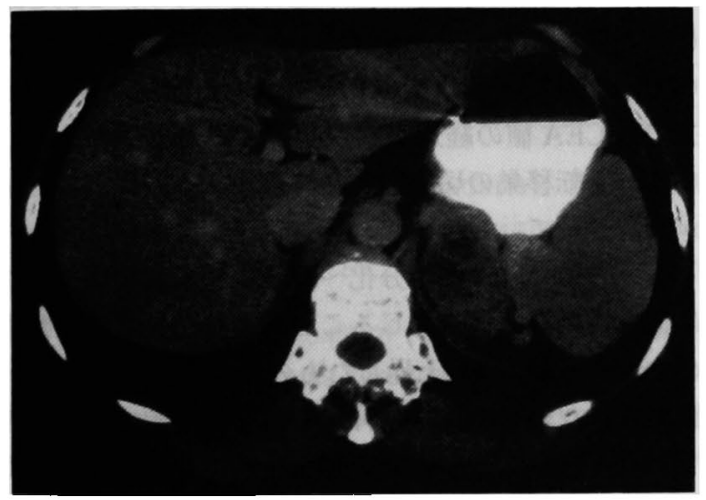

图 1 腹部 CT 検査：肝, 腹腔内リンパ節に転移は認 めなかったが, 左腎上極の前方に隣接して径約 5.5 $\mathrm{cm}$ 大の内部不均一な低濃度腫瘤を認めた。

手術所見：左腹部横切開を行い，左副腎腫瘍を摘出 した. 左副腎は長径 $7.5 \mathrm{~cm}$ と腫大していたものの，被 膜は保たれ周囲藏器への浸潤は認めなかった。流入血 管は怒張，拡張していたが，比較的容易に摘出し得た。

摘出標本：大きさは $7.5 \times 5.0 \times 3.5 \mathrm{~cm}$ であり，重さ は85gであった. 灰白色の充実性腫瘤であり,内部は一 部壊死していた（図了）。

病理組織学的所見：副腎組織を置換して増殖する中 分化型腺癌が認められ, 形態学的には前回の直腸癌の

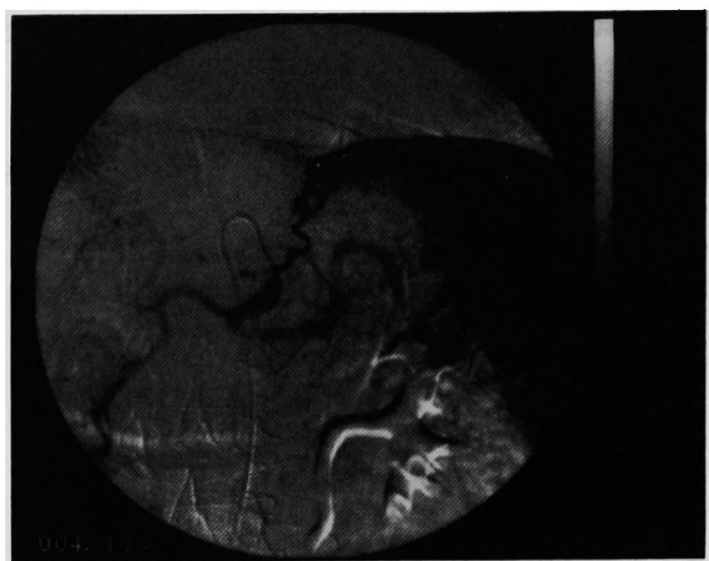

図 2 血管造影検査：左中副腎動脈造影を施行したと ころ, 同動脈は腫大した左副堅により伸展され, 周 曲に不規則微細な tumor stain を認めた. hypovascularであり，転移性腫瘍が強く疑われた。

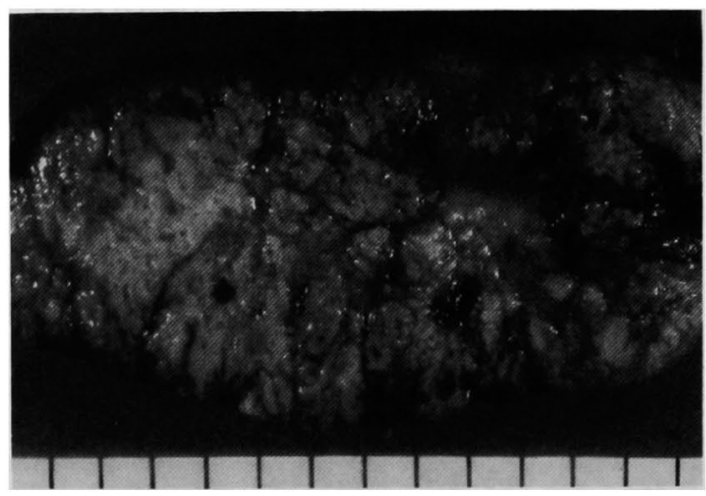

図 3 摘出標本：大きさは $7.5 \times 5.0 \times 3.5 \mathrm{~cm}$ であり, 重さは85gであった. 灰白色の充実性腫瘤であり,内 部は一部罯死していた。

転移病変と考えられた（図 4，5）。

術後経過：術後経過は順調であり, CEAも1.7ng/ $\mathrm{ml}$ に減少, 術後 7 力月後の現在, $\mathrm{CEA}$ の上昇はなく再 発の徴候は認めていない.

\section{考察}

副腎は覀性腫瘍の終末期には比較的多く血行性転移 される蔵器と言われておう, 悪性腫瘍死亡剖検例では $14.8 \%$ に副腎転移巣が認められる ${ }^{11}$. 原発臓器別では, 肺・気管支が最も多く28.1 32.2\%, 続いて胃の 10.3〜22.5\%であり膵, 肝, 乳房の順に続く. 結腸, 直腸は最も少なく $2.7 \%, 2.2 \%$ てある ${ }^{1) 2}$. この理由は, 副腎の血流支配が，主に大循環系であるのに対して， 
結腸，直腸癌の血行性転移は一度門脈を介するためだ と考えられている.

副腎への再発部位については両側副腎が最も多く, 続いて左副腎, 右副腎の順と言われている。この理由

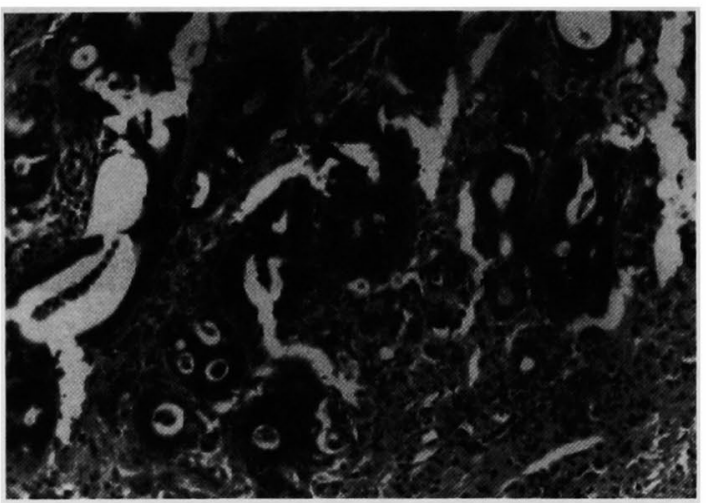

図 4 前回の直腸癌病理組織学的所見：壁外人浸潤す る中分化型腺癌を認めた (H.E 染色 $\times 100)$.

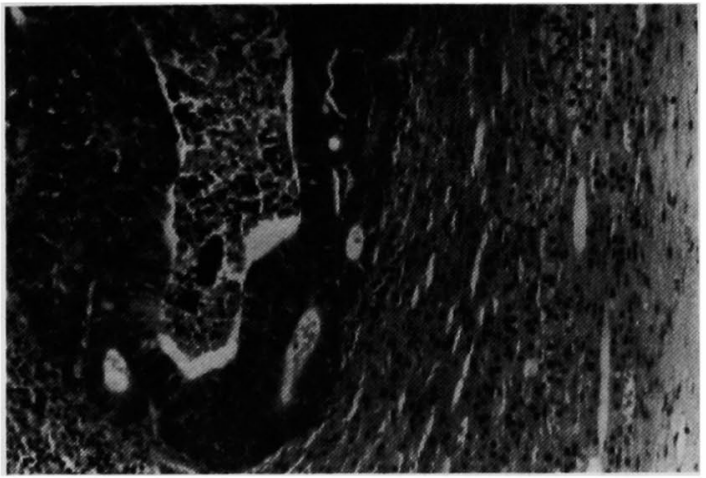

图 5 病理組織学的所見：中分化型腺癌が認められ, 形態学的には前回の直腸癌の転移病変と考えられた $($ H.E 染色 $\times 100)$.
について, Willis ら゙は一般に左副腎は右副腎よりも 大きく，血流も豊富なためだと説明している。

また，一般に副腎転移が悪性腫場の終末期の全身転 移の一部分であることが多いため, 多藏器への転移を 伴わない孤立性副腎転移は非常に少なく, 腫場死亡剖 検例の $1.8 \%$ と報告されている. 中でも北島ら"が消化 器癌のうち胃癌が $0.6 \%$ あるると報告したのに対して， 直腸癌からの孤立性転移は著者らが検索した範囲内で は自験例を含めて 8 例4) 10) と非常に稀である.

続いて，これまでに報告された直腸癌孤立性副腎転 移例について自験例を含めて集計，検討してみた（表 $2)$.

男女比は $5: 3$ と男性にやや多いものの, 明らかな 性差はなかった. 再発部位は左 5 例, 右 3 例であり, 左優位ではあったが Willis の説を支持するだけの根 拠はなかった. Ignacio ら ${ }^{11} か ゙$ 組織型は胃癌では低分 化型胃癌に多いと報告しているが，自験例を含めて中 分化〜高分化が多く, 直腸癌では副腎転移巣切除後の 予後に関与していると思われた。

病期はいずれもII期以上の進行癌であり，1例を除 けば再発まで 1 年以上を要し，外来検査で発見されて いた。 CEAの上昇を契機に発見された症例が多く，外 来での CEA 值の経過観察が必要であると思われた。 いずれも転移巣の切除により, 術後 7 力月以上の生存 が確認されていた。

これらのことから中分化〜高分化型の直腸癌であれ ば孤立性副腎転移を生じることもあり，外来経過観察 において CEA 值が上昇したものの多臓器への転移が 認められない場合には副腎への転移も念頭に置くべき であると思われる．また，発見されたならば切除後の 長期生存例が認められることから，積極的に手術する ことが望ましいと思われる。

表 2 本邦における直腸癌孤立性副腎転移例

\begin{tabular}{|c|c|c|c|c|c|c|c|c|c|c|}
\hline & 発表年 & 年齢 & 性別 & 再発部位 & 組織型, & 苪期 & 再発までの期間 & 発見の契機 & 予後(術後) & 発表者 \\
\hline 1 & 1985 & 71 & 男 & 右 & pap. & II & 2 年 & CEA の上昇 & 8 力月後生存中 & 松井4) \\
\hline 2 & 1987 & 39 & 女 & 左 & 不明 & & 8 年 & CEA の上昇 & 2 年後生存中 & Fujita ${ }^{5)}$ \\
\hline 3 & 1993 & 52 & 男 & 右 & well. & IV & 初発時 & & 2 年 9 月後生存中 & Watatani ${ }^{6)}$ \\
\hline 4 & 1994 & 57 & 男 & 左 & 不明 & & 3 年 4 力月 & $\mathrm{CEA}$ の上昇 & 1 年 6 力月後生存中 & 佐尾山?" \\
\hline 5 & 1995 & 64 & 男 & 左 & well. & II & 2 年 3 力月 & $\mathrm{CEA}$ の上昇 & 1 年 1 力月後生存 & 坂川8 \\
\hline 6 & 1995 & 60 & 女 & 左 & $\bmod$. & II & 1 年 9 力月 & $\mathrm{CEA}$ の上昇 & 1 年 9 力月後生存中 & 中听 \\
\hline 7 & 1995 & 58 & 男 & 右 & well. & II & 1 年 2 力月 & $\mathrm{CT}$ & 2 年 7 月後に死亡 &  \\
\hline 8 & 1997 & 63 & 女 & 左 & mod. & Illa & 1 年 2 力月 & CEA の上昇 & 7 力月後生存中 & 自験 \\
\hline
\end{tabular}




\section{結語}

今回著者らは, 術後 1 年 2 力月目に発生した直腸癌 孤立性副筒転移の1例を経験した。

本邦報告例 7 例とともに文献的考察を加えて報告し た.

\section{文献}

1）北村慎治, 藤永卓治, 大川順正他：転移性副腎腫瑏 の 1 例一 5 年間の日本病理剖検輯報による統計的 検討一. 日泌会誌 $73: 1324-1332,1982$

2）吉住 豊, 島 伸吾, 杉浦芳章他：胃癌副堅転移の 1 切除例。癌の臨 $35: 1669-1704,1989$

3) Willis RA : Secondary tumors of the adrenals in spread of tumors in the human body. 3rd. ed. Butterworth \& Co, London, 1973, p197-207

4）松井 英, 中田雅支, 板部秀文他：孤立性に副腎転 移をした直腸癌の 1 例. 日消外会誌 18 ： 506, 1985

5) Fujita K, Kameyama S, Kawamura M : Surgically removed adrenal metastasis from cancer of the rectum. Dis Colon Rectum 31: 141-143,
1988

6) Watatani $M$, Ooshima $M$, Wada $T$, et al: Adrenal metastasis from carcinoma of the colon and rectum. A report of three cases. Surg Today $23: 444-448,1993$

7) 佐尾山信夫, 吉田 冲, 津田 洋他：直腸癌術後の 転移性副腎腫瘍を切除し得た 1 例. 日消外会誌 $27: 504,1994$

8）坂上太一, 木原真吉，木下諴一他：摘出しえた直腸 澢副堅転移の1例。日臨外医会誌 $56 ： 1436$ 1440,1995

9）中口和則, 陶 文暁, 畠中秀雄他：術後に孤立性副 腎転移をした直腸瘦の 1 例. 日臨外医会誌 56 ： 2149-2152, 1995

10）水谷佐世子, 丸田守人, 宮島伸宣他：直腸暍術後副 腎転移の 1 手術例. 日本大腸肛門病会誌 $48: 330$ $-335,1995$

11) Ignacio D, Osvaldo L : Patterns of metastases in intestinal and diffuse type of carcinoma of the stomach. Human Pathl $12: 237-242,1981$

\title{
A CASE OF RECTAL CANCER WITH A SOLITARY ADRENAL METASTASIS THAT OCCURRED 14 MONTHS AFTER THE OPERATION
}

\author{
Kentaro EMOTO, Tadateru TAKAHASHI, Takayuki NOMIMURA, Ichiro OMORI, \\ Hajime HAYASHI and Yoshitaka KATO \\ Department of Surgery, Hiroshima General Hospital of West Japan Railway Campany
}

Adrenal metastasis of rectal cacer is often encountered, but it is rare that a case of solitary adrenal metastasis which was resectable is very rare. In this paper, we present our experience with such a case together with a review of previous seven cases in the Japanese literature.

The case involved a 63-year-old woman, who underwent an abdominoperineal excision of the rectum and associated resection of the uterus and vagina with a diagnosis of rectal cancer with vagina invasion in February, 1996. Histopathologically it was moderately differentiated adenocarcinoma in Stage IIIa. Thereafter, she was followed on an ambulant basis when a gradual increase in CEA was noted. On CT a left adrenal tumor was found in April, 1997. Endocrine examination revealed no abnormalities, and an extirpation of the tumor was conducted with a suspicion of metastatic adrenal tumor in May. Histological exploration resulted in that the tumor was adrenal metastasis of the rectal cancer. There have been no signs of recurrence, as of 7 months after the operation.

In a review of the seven cases seen in the Japanese literature, long survivors were observed among patients after extirpation of the tumor. So it is desirable to conduct operation aggressively as soon as possible after adrenal metastasis is detected. 